\title{
Modelling Organisational Vicarious Liability
}

\author{
Christian Witting*
}

Abstract: This article identifies two paradigms of vicarious liability. One is an established paradigm of 'liberal agency' found in cases where owner-managers 'act through' workers, with whom they have personal relations, in undertaking work tasks. The second paradigm is found in cases concerning bureaucratic organisations, which are characterised by chains of command and variegated decision-making procedures. Courts have grounded organisational responsibility in features such as structure, hierarchy, and control, which this article uses to construct a model of the 'deterrable organisation'. The deterrable organisation has important capacities to effect change in behaviour that courts rely upon in order to prevent worker wrongdoing. The article tests the viability of the model against the empirical literature and argues that courts could improve outcomes by a more targeted use of powers to award remedies.

Keywords: Tort, vicarious liability, organisations

\section{INTRODUCTION}

In the last decade, UK law on vicarious liability has undergone rapid development. Much academic commentary about this development has been negative in tenor. Concerns have been raised that the doctrine's scope has become uncertain and that its application has

\footnotetext{
* QMUL. Thanks to: Philip Morgan, John Murphy, Martin Petrin, and David Tan; conference participants at the Supreme Court of Queensland, Singapore Management University and University of Edinburgh; and the anonymous reviewers. Dedicated to Emeritus Professor Chris Clarkson.
} 
resulted in bad decisions. ${ }^{1}$ Although certainty might be a necessary casualty of changing laws, an enduring worry about vicarious liability is that the uncertainty surrounding the doctrine reflects the absence of proper justifications for it. ${ }^{2}$ Of course, it is clear that the doctrine allocates responsibility for worker wrongs in order to compensate tort claimants and that compensated claimants are likely to feel a sense of vindication. Academic commentators have few gripes about the pursuit of such aims. However, tort law is 'two-sided' ${ }^{3}$ in nature so that reasoning about liability rules must comprehend the position not only of claimants but of defendants as well. This has been the root problem in justifying vicarious liability because the reasons for its imposition upon employers have failed to convince.

This article argues that, while a liberal notion of agency provides good justification for the vicarious liability of businesses operated by owner-managers who have personal relations with workers and of other organisations with analogous structures, it falls short in relation to medium- and large-size organisations. These 'bureaucratic' organisations feature multiple levels of management, 'chains of command', and variegated decision-making procedures. Senior management directives imposed on workers, without doubt, conclusively establish the existence of 'authority', but authority becomes more difficult to prove when decision-making is devolved and workers are imbued with decision-making discretion. Of course, scholars and judges have attempted to characterise the vicarious liability of bureaucratic organisations as a form of enterprise liability. This entails the imposition of liability upon organisations

\footnotetext{
${ }^{1}$ Eg, P Giliker, 'Analysing Institutional Liability for Child Sexual Abuse in England and Wales and Australia: Vicarious Liability, Non-Delegable Duties and Statutory Intervention’ (2018) 77 CLJ 506, 516, 532 and 534.

2 See J Goudkamp, 'Case Comment: Various Claimants v Barclays Bank Plc' [2017] JPIL C194, C196-7.

${ }^{3}$ Eg, P Cane, Responsibility in Law and Morality (Oxford: Hart, 2002), p 99.
} 
undertaking risky business activities for their own benefit, and from which it is deemed 'fair' to exact compensation for injuries. However, enterprise liability explains only a sub-set of cases. It suffers from the substantial flaws of being inapplicable to non-profit employers, such as public authorities and charities, and, when viewed as a 'licence fee' upon organisational activities, of actually tolerating employee wrongdoing. ${ }^{4}$

This article isolates elements of judicial reasoning found in modern cases of organisational vicarious liability. From factors including structure, hierarchy, and control, it constructs a model of the 'deterrable organisation'5 and demonstrates how courts might achieve reform of worker behaviour through the imposition of vicarious liability. Three themes inform the model. The first relates to strict liability, which is liability regardless of fault. The imposition of strict liability creates incentives to be proactive in setting proper standards of conduct. The second theme is about 'delegation'. Because vicarious liability does not require proof of organisational fault, it pushes responsibility for investigations of worker wrongdoing, and for reform of conduct, onto organisations themselves. This structuring of responsibility mirrors decentred regulatory practices. The third theme relates to 'deterrability', which arises from organisational attributes that courts rely upon in order to reduce the frequency and seriousness of worker wrongdoing. The model hypothesises that organisations are deterrable because they can act on threats of legal liability by planning

\footnotetext{
${ }^{4}$ Eg, JCP Goldberg and BC Zipursky, 'The Strict Liability in Fault and the Fault in Strict Liability' (2016) 85 Fordham LR 743, 763-4.

${ }^{5}$ This phrase is used in LM Friedman, Impact: How Law Affects Behavior (Cambridge, Mass.: Harvard University Press, 2016), p 134.
} 
activities, devising proper standards of conduct which override individual discretion, and compelling workers to adhere to them.

Having set out a model of the deterrable organisation, the article turns to consider scholarly concerns about deterrence reasoning, the ostensible problems being that subjects of law are not well-informed about legal rules, that they ignore incentives to comply, and that those incentives are dampened by liability insurance. Although these concerns turn out to be of lesser relevance to medium- and large-size organisations, the article assesses potential weaknesses in the deterrable organisation model and acknowledges ways in which the reform of worker behaviour might be frustrated. The conclusion is that, although organisations are deterrable, there will be insufficient deterrence unless steps are taken to reinforce the operation of the model by a more targeted use of powers to award remedies.

In constructing its argument, this article adopts a Dworkinian interpretive approach. This widely-adopted approach to theorising about private law $w^{6}$ encompasses three stages. At the pre-interpretive stage, we identify 'the rules and standards taken to provide the tentative content of the practice' in question. ${ }^{7}$ At the interpretive stage, the 'interpreter settles on some general justification for the main elements of the practice identified at the preinterpretive stage'. ${ }^{8}$ This involves putting forward an 'interpretive proposal', which attempts to provide the best possible way of seeing the rules and standards. This way of seeing, or justification, 'need not fit every aspect or feature of the' rules and standards, but must fit

\footnotetext{
${ }^{6}$ See, eg, SA Smith, Contract Theory (Oxford: Oxford University Press, 2004), p 5.

${ }^{7}$ R Dworkin, Law's Empire (Oxford: Hart, 1998), pp 65-6.

8 Ibid p 66.
} 
them sufficiently so as not to constitute the invention of something new and unintended. ${ }^{9}$ If satisfactory, the interpretive proposal should help us to understand the law better. ${ }^{10}$ At the post-interpretive stage, the interpreter 'adjusts' her sense of what the rules and standards really require 'so as better to serve the justification' which has been proposed and assist in making the rules or standards work better. ${ }^{11}$

\section{LIBERAL AGENCY ${ }^{12}$}

Our discussion commences with the first paradigm of vicarious liability. Prior to the late $17^{\text {th }}$ century, English courts imposed vicarious liability on the basis of what the master 'commanded' the servant to do. In modernising the law, Lord Holt insisted upon the presence of an agency relationship between master and servant but recognised, for example in Turberville $v$ Stamp, that implied authority would be sufficient to support liability. ${ }^{13}$ In this, he is said to have introduced a rule of responsibility based upon 'convenience and public policy'. ${ }^{14}$ Within a century, vicarious liability rules became focussed upon the key concept of the 'relationship of employment'. ${ }^{15}$ Even so, the 'scope of employment' was determined by examining what activities the employee was authorised to engage in.

\footnotetext{
9 Ibid pp 52 and 66.

${ }^{10}$ Smith, above n6, p 5 .

${ }^{11}$ Dworkin, above $\mathrm{n7}, \mathrm{pp} 57$ and 70.

12 The term derives from A Gray, Vicarious Liability: Critique and Reform (Oxford: Hart, 2018), p 9.

12 TFT Plucknett, A Concise History of the Common Law (Indianapolis: Liberty Fund, 5th edn, 1956), p 166.

13 (1697) 1 Ld Raym 264, 264-5; 91 ER 1072, 1073.

14 Plucknett, above n12, p 476.

${ }^{15}$ Eg, M'Manus v Crickett (1800) 1 East 106; 102 ER 43.
} 
It remains necessary to undertake this inquiry in classical vicarious liability cases because the mere fact of employment says nothing about whether the employee was acting on instruction or was off on a frolic. The normatively salient link between the owner-manager and the employee, where an act of the latter causes harm to the claimant, is the authorised activity. ${ }^{16}$ The concept of agency used is not 'technical' in the sense of being premised upon agreement to act and specification of the agent's area of authority. It turns, instead, on the idea of one person 'acting through another' in order to fulfil her purposes. ${ }^{17}$

In recent times, judges have moved away from the language of the older authorities, in order to accommodate a widening of 'employer' responsibilities so as to include activities undertaken by non-employees. Courts consider the worker's 'field of activities' and their connection to the commission of the tort. ${ }^{18}$ However, extended consideration of this approach in Bellman v Northampton Recruitment $L t d^{19}$ reveals two important things. First, the 'field of activities' concept inevitably requires reference to issues of authority, because one can discern the 'field' only according to what the employer was intending to accomplish by engagement of workers. Second, the relevant notion of authority extends beyond both actual and ostensible authority, so that it comports with the traditional, liberal notion of agency.

\footnotetext{
${ }^{16}$ The centrality of agency reasoning is championed by Gray, $\mathrm{n} 12, \mathrm{pp} \mathrm{x}, 50$ and 187, and accepted here as the most cogent justification of classical law. Cf C Beuermann, 'Tort law in the employment relationship: A response to the potential abuse of an employer's authority' (2014) 21 TLJ 169.

${ }^{17}$ Eg, Morgans v Launchbury [1973] AC 127, 135.

${ }^{18}$ Mohamud v Wm Morrison Supermarkets plc [2016] AC 677, [44]-[45]('Mohamud').

${ }^{19}$ [2019] IRLR 66, esp [17]-[18], [22] and [24].
} 
The potential remains for the vicarious liability of small companies, ${ }^{20}$ small partnerships, ${ }^{21}$ and individual employers on the basis of liberal agency where there are personal relations between relevant parties. The justification applies, for example, where a worker commits a tort with a sufficient connection to a family plumbing business's field of activities because its manager has set the worker on a particular course, ${ }^{22}$ perhaps wearing a distinctive uniform, driving a logo-emblazoned van, ${ }^{23}$ and acting with the owner-manager's attitudes and values. ${ }^{24}$ But the owner-manager's actual grant of authority is not definitive of the extent of the business's vicarious liability because the presence of some minimal degree of authority in the worker is likely to create expectations among counterparties as to standards to be upheld and responsibilities undertaken, and because the owner-manager must be assumed to understand the tendencies of workers to take shortcuts and exploit opportunities for self-gratification.

Although Gray is right to explain vicarious liability by reference to ideas of liberal agency, he does not see modern cases of responsibility for the acts of intentional wrongdoers, such as those involving sexual abuse of children, as being consonant with the doctrine's agential foundations. ${ }^{25}$ This is because the worker does not act both for the employer's purposes and benefit. ${ }^{26}$ Undoubtedly, this is true - so far as it goes. But Gray argues, further, that employers

\footnotetext{
${ }^{20} \mathrm{Eg}$, Bellman v Northampton Recruitment Ltd [2019] IRLR 66.

${ }^{21}$ See Dubai Aluminium Co Ltd v Salaam [2003] 2 AC 366.

22 PS Atiyah, Vicarious Liability in the Law of Torts (London: Butterworths, 1967), p 13.

${ }^{23}$ See Hollis v Vabu (2001) 207 CLR 21.

${ }^{24}$ C Hodges, Law and Corporate Behaviour (Oxford: Hart, 2015), p 38. See also MJ Hatch, Organization Theory: Modern, Symbolic, and Postmodern Views (Oxford: Oxford University Press, 3rd edn, 2013), p 103.

${ }^{25}$ Gray, above n12, p 172.

${ }^{26} \mathrm{Ibid}$ pp 159 and 172.
} 
ought not to be made responsible for the commission of torts in such circumstances. Consistent with corrective justice values, he propounds the view that tort law ought to be confined either to cases of fault-based liability or those in which the employer is morally blameworthy for the commission of employee wrongs. ${ }^{27}$ At least a couple of objections arise. First, the argument ignores tort law's two-sided nature, which necessitates that judges consider both agent actions and the interests of persons harmed by those actions in coming to decisions about liability. In tort cases, 'the interests of victims are given at least as much weight as those of agents' ${ }^{28}$ Second, Gray clings to notions of fault developed in a simpler age and seeks to apply them not only to cases involving small organisations characterised by personal relations with workers, but to cases involving bureaucratic organisations too. In treating these cases alike, he elides important differences between them that ground the case for a second paradigm of vicarious liability.

\section{THE ORGANISATIONAL TURN IN THE CASE LAW}

The classical rules of vicarious liability were sufficient in times agricultural production, smallscale business, and size-limited partnerships because owner-managers interacted directly with workers. Then came the industrial revolution and the growth of bureaucratic organisations. New justifications for vicarious liability were required. Until Various Claimants

$v$ Catholic Child Welfare Society $(C C W S){ }^{29}$ the normatively important features of organisational vicarious liability remained unclear. The embrace of a new kind of vicarious liability in CCWS reflects the transition to a corporatised world characterised by collective

\footnotetext{
${ }^{27} \mathrm{Ibid}$ pp 159 and 178.

${ }^{28}$ Ibid p 99.

${ }^{29}$ [2013] 2 AC 1.
} 
action, continuous planning and operations to scale. ${ }^{30}$ The larger size and scale of industrial, commercial, and governmental activities has led to the growth of multi-level management, featuring the indirect communication of decisions down the hierarchy of authority and/or devolved decision-making. In medium- and large-size organisations, directors and senior managers interact primarily with middle-managers and no longer see or know anything of individual workers. ${ }^{31}$ Proving authority to act is complicated by the sharing of tasks among workers and by the existence of areas of decision-making discretion. Workers imbued with decision-making discretion might need to determine what to do after reconciling direct requests, company policies, past practices, customer expectations, and so on. In the circumstances, assignment of liability for wrongdoing on simple agency grounds frequently is 'inadequate because most injuries result from a complicated combination of acts by various agents' or from the exercise of discretion. ${ }^{32}$ The difficulty in proving agency is greatest when worker actions diverge from the norm and are characterised by courts as wrongs.

The advent of bureaucratic organisations is not the only change in the world of work that has impacted upon vicarious liability rules. For decades, employers have been outsourcing work when this either is more efficiently undertaken by suppliers of specialist inputs or else helps to avoid unwanted employment responsibilities. ${ }^{33}$

\footnotetext{
${ }^{30}$ See AD Chandler, Scale and Scope (Cambridge, Mass.: Harvard University Press, 1990), ch 2; GC Keating, 'The Idea of Fairness in the Law of Enterprise Liability' (1997) 95 Mich LR 1266, 1267.

${ }^{31} \mathrm{H}$ Mintzberg, The Structuring of Organizations (Englewood Cliffs: Prentice-Hall, 1979), pp 242-4.

32 LA Kornhauser, 'An Economic Analysis of the Choice Between Enterprise and Personal Liability for Accidents' (1982) 70 Cal LR 1345, 1350.

${ }^{33}$ Eg, P Giliker, Vicarious Liability in Tort (Cambridge: Cambridge University Press, 2010), p 82.
} 
Reflecting these structural changes, the modern law of vicarious liability has become more capacious through: extension of liability to persons 'akin to employees' and then to certain independent contractors ${ }^{34}$ (explaining use of the term 'worker' in this article); ${ }^{35}$ the development of a 'sufficient connection' test ${ }^{36}$ which extends responsibility for the commission of torts beyond cases of authorisation to encompass unauthorised acts occurring in broadly-conceived 'fields of activity'; ${ }^{37}$ and the adoption of rationales for liability aimed at addressing new organisational practices. ${ }^{38}$ These changes have been accompanied by a greater focus on organisational capacities to coordinate work and constrain worker conduct. The result is a more complete type of organisational responsibility. But the question is how this is to be justified.

This article aims both to model and critique organisational vicarious liability. In doing so, it focusses on how courts have justified modern developments. Their decisions have turned upon the following elements: First, courts have been right to observe that most defendants are organisations. ${ }^{39}$ They include not just companies, but government departments, statutory authorities, partnerships, non-profit organisations, and unincorporated associations. Courts have been willing to impose liability upon unincorporated associations where they act 'like' corporate bodies, ${ }^{40}$ as was the case with

\footnotetext{
${ }^{34}$ Eg, Various Claimants v Catholic Child Welfare Society [2013] 2 AC 1 ('CCWS').

35 'Worker' is a term encompassing persons at all levels within organisations but, for expositional purposes, a contrast is drawn frequently between 'managers' and 'workers'.

${ }^{36}$ Lister v Hesley Hall Ltd [2002] 1 AC 215.

${ }^{37}$ Bellman v Northampton Recruitment Ltd [2019] IRLR 66, [17].

${ }^{38}$ Eg, CCWS [2013] 2 AC 1; Armes v Nottinghamshire County Council [2018] AC 355 ('Armes').

${ }^{39}$ CCWS [2013] 2 AC 1, [34].

40 lbid [34].
} 
the Institute of Brothers in CCWS. ${ }^{41}$ Second, organisations are characterised by hierarchical relationships between senior managers and individual workers. ${ }^{42}$ Thus, in CCWS the "brothers were subject to ... directions as to their employment [with third party schools] and the general supervision of the Provincial, their superior within that hierarchical structure' ${ }^{43}$ Third, these hierarchical relationships provide organisations with the ability to exercise control over work. ${ }^{44}$ More specifically, they exercise 'managerial control' ${ }^{45}$ which facilitates measures to discipline workers and/or reform the ways in which they undertake work. For example, in Armes $v$ Nottinghamshire County Council the local authority retained statutory powers of inspection, supervision, and removal with respect to children residing with approved foster parents. ${ }^{46}$ Fourth, courts have noted that workers frequently are an 'integral part' of organisations while undertaking tasks that result in wrongdoing. ${ }^{47}$

Beyond these elements of organisation, courts rely also upon reasoning that is more philosophical in nature. Two major theories have attracted their attention. First, enterprise liability. Using their own terminology, courts find it significant that the organisation or 'enterprise' conducts a 'business' activity and 'benefits' from work undertaken. The benefit need not be financial in nature but can comprise anything of value to the organisation. Thus, in Cox v Ministry of Justice the prisoners' work in the kitchen 'form[ed] part of the operation

\footnotetext{
41 Ibid [89].

42 Ibid [2].

43 Ibid [89].

${ }^{44}$ Eg, Cox v Ministry of Justice [2016] AC 660, [21].

${ }^{45}$ Mutua v Foreign and Commonwealth Office [2012] EWHC 2678 (QB), 82.

46 [2018] AC 355, [10].

${ }^{47}$ Eg, Cox v Ministry of Justice [2016] AC 660, [22]-[24].
} 
of the prison, and [was] of direct and immediate benefit to the prison service itself' ${ }^{48}$ The problem is that the benefit can be obtained only through the creation or exacerbation of risks to others. ${ }^{49}$ As such, it is 'fair' to impose liability on the organisation for the negative consequences of its activities. ${ }^{50}$

Second, courts assert that vicarious liability is imposed upon organisations because they can 'do something' about workers conduct. ${ }^{51}$ They embrace a deterrence rationale based on judicial 'power to order defendants to pay damages' and the consequent ability to 'deter the defendant and other similarly situated actors from engaging in conduct they deem undesirable; at least insofar as the threat of damages awards affects actors' decisions' ${ }^{52}$ For example, Sir Anthony Clarke MR in Gravil v Carroll stated that the imposition of vicarious liability upon a rugby club for player wrongdoing was justified by 'deterrence of the club by bringing home the liability ... so as to prevent or minimise the risk of foul play in the future'. ${ }^{53}$ His Lordship discussed specific actions that the club could take to this end. While in other cases deterrence is not referred to by name, it is the substantive explanation for what courts seek to achieve. Thus, in Various Claimants v Wm Morrison Supermarkets plc, Justice Langstaff (at first instance) noted that an employer could design preventative systems that workers

\footnotetext{
48 Ibid [34].

${ }^{49}$ CCWS [2013] 2 AC 1, [87].

${ }^{50}$ Armes [2018] AC 355, [61].

51 Ibid [67].

52 JCP Goldberg, 'Twentieth-Century Tort Theory' (2003) 91 Geo LJ 513, 525.

53 [2008] EWCA Civ 689, [26].
} 
could be directed to observe. ${ }^{54}$ Such statements tell us that courts are not indifferent to the impact of vicarious liability. It is reform of worker behaviour that they desire.

\section{EXISTING EXPLANATIONS OF VICARIOUS LIABILITY}

In 'interpreting' judicial reasoning, Dworkin urges us to search for the best way to justify it, to see it in its 'best light'. The question arises whether enterprise liability presents organisational vicarious liability in its best light. ${ }^{55}$ Enterprise liability has a respectable pedigree, ${ }^{56}$ having been developed in the scholarly literature during the first half of the twentieth-century, and been used as a justification for US law on products liability and vicarious liability. ${ }^{57}$ It is concerned with ensuring that organisational defendants, such as manufacturers and large firms, cannot escape responsibility for injuries caused by profit-making activities. Beyond this basic idea, different branches of the theory encompass different - and partly conflicting sub-goals, the main ones being: the spreading of costs of injury to consumers in the sale of goods and/or to insurers via higher premiums; ${ }^{58}$ the internalisation by organisations of the costs of their activities, so as to ensure that the most appropriate (not excessive or damaging)

\footnotetext{
54 [2018] EMLR 12, [184] (affirmed [2018] EWCA Civ 2339).

55 See S Waddams, Dimensions of Private Law: Categories and Concepts in Anglo-American Legal Reasoning (Cambridge: Cambridge University Press, 2003), p 102.

${ }^{56} \mathrm{Eg}, \mathrm{J}$ Gordley, Foundations of Private Law: Property, Tort, Contract, Unjust Enrichment (Oxford: Oxford University Press, 2006), p 205.

${ }^{57}$ GL Priest, 'The Invention of Enterprise Liability: A Critical History of the Intellectual Foundations of Modern Tort Law' (1985) $14 \mathrm{~J}$ Legal Stud 461. It is the 'most influential' theory of vicarious liability: D Tan, 'Taking two bites at the cherry: vicarious liability and non-delegable duty' (2018) 134 LQR 193, 195.

${ }^{58}$ Eg, Keating, above n30, pp 1273 and 1330.
} 
levels of activity are undertaken; ${ }^{59}$ and the deterrence of future wrongdoing. ${ }^{60}$ Courts have not explored these different sub-goals in any depth - although they have tended to adopt the deterrence view. Indeed, until recently, courts had not even considered what an 'enterprise' is, fostering uncertainty about vicarious/enterprise liability's scope and explanatory power. ${ }^{61}$

These concerns aside, enterprise liability suffers from two flaws that undercut its justificatory power and call for a new model of organisational vicarious liability. The first flaw arises from its inability to encompass organisations that do not operate pursuant to ordinary profit motives. While the owners and managers of businesses operated for profit derive personal benefits from imposing risks on others, ${ }^{62}$ this is not the case with non-profit bodies. Those in charge of government departments, public authorities, and charities are 'otherregarding', and have as their primary concern the needs of third parties. ${ }^{63}$ The 'benefits' of risk imposition arising from their activities accrue to third parties and not to those in charge. ${ }^{64}$ So, whereas the imposition of risk-for-profit at the heart of enterprise liability has an exploitative quality to it, this does not characterise the activities of non-profits. The second flaw is that enterprise liability is not treated always as a theory directed towards reform of organisational activity. Indeed, some see it as little more than a 'licence fee' on activities

\footnotetext{
${ }^{59} \mathrm{Eg}$, GC Keating, 'The Theory of Enterprise Liability and Common Law Strict Liability' (2001) 54 Vand LR 1285, 1286.

${ }^{60}$ See, eg, Kornhauser, above n32, pp 1346 and 1349-50.

${ }^{61} \mathrm{~J}$ Morgan, 'Vicarious liability for independent contractors?' [2015] PN 235, 241.

${ }^{62} \mathrm{~N}$ Mendelson, 'A Control-Based Approach to Shareholder Liability for Corporate Torts' (2002) 102 Colum LR $1203,1253 \mathrm{ff}$.

${ }^{63}$ EW Orts, Business Persons: A Legal Theory of the Firm (Oxford: Oxford University Press, 2013), p 205.

${ }^{64} \mathrm{Eg}$, E v English Province of Our Lady of Charity [2013] QB 722, [109]; Cf D Tan, 'Internalising Externalities: An Enterprise Risk Approach to Vicarious Liability in the 21st Century' (2015) SAcL 822, 841
} 
which, although desirable, cause occasional injuries. ${ }^{65}$ This treats worker wrongdoing as a matter of indifference. ${ }^{66}$

The best that we can say about enterprise liability is that it looks in the right direction by providing an explanation of vicarious liability that is not reliant upon agency, but which takes into account the organisational status of defendants and provides support for the imposition of liability upon profit-making businesses. However, initial steps have been taken towards identifying a more comprehensive theory. Stone adverted to important internal features of large business organisations by describing them as 'bureaucracies', characterised by information flows, managerial control, and the ability to plan for the future. In an increasingly bureaucratic world, wrongdoing was attributable to 'flaws in the organization's formal and informal authority structure, or in its information pathways' ${ }^{67} \mathrm{~A}$ potential solution was to impose 'direct and selective constraints on how ... managers work out various internal relationships' ${ }^{68}$ In another take on these issues, Deakin predicted that the 'fragmentation of enterprise' through practices such as out-sourcing would entail a move towards 'organisational liability'. ${ }^{69}$ He wrote also about organisational amenability to deterrence incentives and about the exercise of 'managerial control' to reduce risks. ${ }^{70}$ These writings

\footnotetext{
${ }^{65}$ Goldberg and Zipursky, above n4, pp 763-4.

${ }^{66} \mathrm{~A}$ step not yet taken in the literature.

${ }^{67}$ C Stone, 'The Place of Enterprise Liability in the Control of Corporate Conduct' (1980) 90 Yale L 1, 5-6, 8 and 31.

68 lbid p 8.

${ }^{69}$ S Deakin, “"Enterprise-Risk”: The Juridical Nature of the Firm Revisited' (2003) 32 Ind LJ 97, 97.

70 Ibid p 101.
} 
provide helpful insights into what a theory of organisational vicarious liability ought to look like.

\section{ORGANISATIONAL VICARIOUS LIABILITY}

For present purposes, it is best to consider the justification of vicarious liability in mediumand large-size organisations by taking an initial step back from these theoretical prompts in order to consider first principles. The standard judicial refrain is that tort law (taken as a whole) has the twin aims of compensating tort victims and deterring future wrongdoing. ${ }^{71}$ Vicarious liability fulfils the compensatory aim in an uncomplicated way. As for deterrence, the assumption is that rules of law have a positive effect on behaviour. They are predicated on legal subjects having knowledge of the rules and of the consequences of breaching them. In tort law, the deterrence argument appears to be soundest with respect to torts that provide explicit definitions of wrongdoing, such as battery and assault. This is because tort rules of this nature perform a guidance function. ${ }^{72}$ The deterrence argument appears sound, also, with respect to negligence because courts spell out precautions for particular types of risk-taking. But what about vicarious liability, which is a rule of strict liability? Here the deterrence justification presents a puzzle because, in determining cases, courts do not formulate specific behavioural guidelines or precautions to be taken. All that they do is to state that, if a worker commits a tort in the field of employer-assigned activities, the employer will be held strictly liable for sufficiently-connected harms to third parties. Can such a rule deter wrongdoing?

\footnotetext{
${ }^{71}$ Eg, Michael v Chief Commissioner of South Wales Police [2015] AC 1732, [127].

72 P Cane, Key Ideas in Tort Law (Oxford: Hart, 2017), p 2.
} 
Organisational vicarious liability embodies a form of 'mediated deterrence' because the organisation is made responsible for altering the behaviour of its workers. ${ }^{73}$ The idea to be tested is that this is a cogent practice because organisations are 'deterrable' parties, vicarious liability being a means of inducing from them the development of proper standards of worker conduct. This might occur through: specific deterrence, pursuant to which organisations that have had vicarious liability awards made against them take action to prevent the future commission of torts; and/or general deterrence, whereby vicarious liability awards impact upon organisations more generally because they either fear future claims or want, simply, to be good corporate citizens. ${ }^{74}$ Being of a forward-looking nature, vicarious liability arises irrespective of whether organisations actually take sufficient care. By eliminating any no-fault escape route, the doctrine creates on-going incentives for organisations to prevent the commission of worker wrongs.

In modelling the deterrable organisation, three foundational themes require exploration. These concern strict liability, the delegation of standard-setting that occurs under strict liability, and the nature of organisation. After exploring these themes, the article examines empirical evidence on deterrence and assesses the 'blockages' that could frustrate its goals.

\section{(a) Strict liability}

\footnotetext{
73 M Dan-Cohen, Rights, Persons and Organizations (New Orleans: Quid Pro Quo, 2nd edn, 2016), p 106.

${ }^{74}$ See, eg, Friedman, above n5, p 97; Hodges, above n24, p 48.
} 
Ever since courts eschewed actual authorisation of tortious acts as a necessary predicate to vicarious liability, the doctrine has been one of strict liability. This has been a source of difficulty for theorists who believe that modern tort law is grounded in, and justified by reference to, fault. ${ }^{75}$ In order better to understand the nature and effect of vicarious liability, it is important to explore what strict liability entails. Typical statements include Lord Hobhouse's declaration in Lister v Hesley Hall Ltd that vicarious liability is 'strict' because 'there has been no actual fault on the part of the employers',${ }^{76}$ and Lord Nicholls' averment in Dubai Aluminium Co Ltd v Salaam that '[v]icarious liability involves the notion that, vis-àvis third parties, the employer, although personally blameless,... is liable for the fault of another'. ${ }^{77}$ Such statements cannot mean that vicarious liability arises only in cases of blameless employers. Indeed, contrary to what some judges and commentators assume, strict liability is not liability in the absence of fault. It is liability regardless of whether the defendant engaged in conduct that breached a legally specified standard'. ${ }^{78}$ Under strict liability, the court does not inquire into fault because this is unnecessary. ${ }^{79}$ The vicariously liable employer's conduct might have been 'innocent', but that is not inevitable - as was acknowledged in Bernard $v$ Attorney General of Jamaica, where Lord Steyn observed that there will 'be cases of vicarious liability where employers were at fault' ${ }^{80}$ Indeed, Abraham

\footnotetext{
${ }^{75} \mathrm{Eg}$, Gray, above $\mathrm{n} 12$.

76 [2002] 1 AC 215, [55] (emphasis in original).

77 [2002] 2 AC 366, [47].

${ }^{78}$ Cane, above n3, p 82 (emphasis added); T Honoré, Responsibility and Fault (Oxford: Hart, 1999), p 23.

${ }^{79}$ F James, 'Vicarious Liability' (1954) 28 Tulane LR 161, 166.

80 [2005] IRLR 398, [21].
} 
asserts that vicarious liability is imposed on some types of defendant as a surrogate for findings of expected negligence. ${ }^{81}$

One of the primary reasons for the attractiveness of vicarious liability is that it removes the need to prove fault. ${ }^{82}$ This is helpful especially when defendants are complex organisations and claimants have no knowledge of their internal workings. Worker negligence typically involve a combination of individual slips, latent conditions, and local factors. ${ }^{83}$ Latent conditions frequently result from senior management decisions, ${ }^{84}$ but it can be difficult to obtain evidence of fault at this level of decision-making. Indeed, whether torts committed are accidental or intentional, it might be difficult for claimants to access information about 'what went wrong ${ }^{\prime 85}$ because organisations refuse to cooperate or because it is difficult to extract salient features from the evidence. Where professional assistance is required to construct a case of organisational fault, this is likely to be costly for claimants.

Where evidence of what went wrong is available, there is still another step that a court must take in deciding whether an organisation was at fault. This is to specify the appropriate standard of care that should have been observed and to determine whether the defendant's conduct fell below it. In straightforward cases (even those involving vicarious liability ${ }^{86}$ ),

\footnotetext{
${ }^{81}$ KS Abraham, 'Individual Action and Collective Responsibility: The Dilemma of Mass Tort Reform' (1987) 73 Virginia $L R$ 845, 855.

${ }^{82}$ Giliker, above n33, p 41.

${ }^{83}$ J Reason, Managing the Risks of Organizational Accidents (Farnham, Surrey: Ashgate, 1997), pp 10, 11 and 1618.

${ }^{84} \mathrm{Ibid}$ pp 5 and 10.

${ }^{85}$ Bazley v Curry [1999] 2 SCR 534, [32].

${ }^{86}$ Eg Gravil v Carroll [2008] ICR 1222, [26]-[27].
} 
courts specify precautions that should have been taken. But this becomes more difficult as organisations become more bureaucratic. As such, another reason for imposing strict liability is that it places an onus upon organisations to do all that they can to promote proper standards of conduct and prevent worker wrongdoing. ${ }^{87}$ This is more likely to be an effective strategy when organisations understand that they inevitably will be made liable for the consequences of worker wrongdoing. ${ }^{88}$ Fixing them with responsibility should result in either lower activity levels ${ }^{89}$ or more effective precaution-taking. ${ }^{90}$ As to the latter, vicarious liability 'focuses energies on prevention, on systematic and proactive efforts rather than discrete reactions to specific known instances of misconduct...' ${ }^{91}$

\section{(b) Co-option/delegation}

Whereas fault-based rules require that claimants obtain information about the internal workings of organisations and ways of addressing risks, strict liability makes this irrelevant. Under vicarious liability, responsibility for standard-setting is 'delegated' to organisations themselves. ${ }^{92}$ If organisations want to avoid liability, the onus is upon them to take action. '[A] strict liability standard [overcomes] the information asymmetry problem. With a strict

\footnotetext{
${ }^{87}$ Eg, Mohamud [2016] AC 677, [62]; DA DeMott, 'Organizational Incentives to Care about the Law' (1997) 60 Law and Contemp Problems 39, 54.

${ }^{88}$ WK Viscusi and RJ Zeckhauser, 'Deterring and Compensating Oil-Spill Catastrophes: The Need for Strict and Two-Tier Liability' (2011) 64 Vand LR 1717, 1745.

${ }^{89}$ KS Abraham, 'Strict Liability in Negligence' (2012) 61 DePaul LR 271.

${ }^{90}$ I Gilead, 'On the Justifications of Strict Liability' in H Koziol and BC Steininger (eds), European Tort Law 2004 (Vienna: Springer, 2004), pp 31 and 48.

${ }^{91}$ DeMott, above n87, p 54.

92 Ibid p 54.
} 
liability standard, only the ... firm need know what the [necessary] level of care is and whether the firm has met it'. ${ }^{93}$

The cogency of delegation becomes apparent upon consideration of the parallels between it and modern regulatory practice. The context is one of a society characterised by 'coordination problems', ${ }^{94}$ which arise because persons live and work together in close cooperation. This entails a high degree of interdependence within workplaces and wider communities. Interactions in these settings present significant risks of harm-doing, and a basic function of tort law is to stimulate the development of standards of conduct that mitigate risks. ${ }^{95}$ Many view the 'organisational transformation of society' as presenting an appropriate means of doing this. ${ }^{96}$ Indeed, a 'decision concerning an organisation is ... more likely than one pertaining to an individual to reverberate through the system, affecting in various ways other organisations and, through them, multitudes of individuals' ${ }^{97}$ Medium- and large-size organisations have important capacities for planning and coordinating the work of large numbers of people, and conduct operations on a recurring basis. ${ }^{98}$ Tort suits against them become 'occasions for judges ... to regulate behaviour on a forward-looking basis', thus making tort law an 'important component of the ... administrative state' ${ }^{99}$

\footnotetext{
${ }^{93}$ Viscusi and Zeckhauser, above n88, p 1745.

${ }^{94} \mathrm{Eg}$, JA Henderson, 'The Constitutive Dimensions of Tort Law: Promoting Private Solutions to Risk-Management Problems (2013) 40 Fla St ULR 221, 221-2.

${ }^{95}$ See eg Cane, above n3, p 184.

${ }^{96}$ Dan-Cohen, above n73, p 121; See also R Baldwin, M Cave and M Lodge, Understanding Regulation: Theory, Strategy, and Practice (Oxford: Oxford University Press, 2nd edn, 2012), pp 139, 147-8 and 289.

97 Dan-Cohen, above n73, p 123.

98 Ibid pp 124 and 125.

99 Goldberg, above n52, p 524.
} 
The goals of regulation are similar in many ways, encompassing the proper understanding of risks of activity, ${ }^{100}$ forward planning, and the formulation of general standards of conduct. ${ }^{101}$ Formerly, regulation was conceived of as involving vertical relationships between regulatory agencies and subjects of regulation under the 'command-and-control' model. This model features legislation either prohibiting conduct outright or formulating standards for its occurrence, inspections by regulatory agencies which enforce standards through prosecutions and civil suits, and the drawing up of schedules of penalties for noncompliance. ${ }^{102}$ The effectiveness of the command-and-control model has declined in a world of fast-changing markets, ${ }^{103}$ high volumes of manufacture, distribution and transacting, ${ }^{104}$ faltering regulatory agency expertise, and limited enforcement budgets. ${ }^{105}$ Without the adoption of innovative methods of regulation, there would be large gaps in standard-setting. 'In many cases, therefore, the regulatory choice is ... whether to prevent a given activity entirely ... or to rely upon market participants to set appropriate standards through the decisions they make in seeking to act in accordance with regulatory principles or rules' ${ }^{106}$

\footnotetext{
${ }^{100}$ Baldwin, Cave and Lodge, above n99, p 83.

${ }^{101}$ See C Macrae, 'Regulating resilience? Regulatory work in high-risk arenas' in B Hutter (ed), Anticipating Risks and Organising Risk Regulation (Cambridge: Cambridge University Press, 2010), pp 141-3 and 153.

${ }^{102}$ Eg, J Black, 'Critical Reflections on Regulation' (2002) 27 Aust J Leg Phil 111.

${ }^{103}$ Eg, F Saurwein, 'Regulatory Choice for Alternative Modes of Regulation: How Context Matters' (2011) 33 Law \& Policy $334,344$.

${ }^{104}$ D Rouch, 'Self-regulation is dead: long live self-regulation' (2010) 4 Law \& Fin Mkt Rev 102, 107.

${ }^{105}$ B Fisse and J Braithwaite, Corporations, Crime and Accountability (Cambridge: Cambridge University Press, 1993), p 196.

${ }^{106}$ Rouch, above n104, p 107.
} 
Modern, decentered approaches to regulation involve governmental and nongovernmental actors operating at different levels, many standards being determined either by industry associations adopting codes of conduct or by individual organisations taking a systems approach to risk management ${ }^{107}$ and devising relevant policies and procedures. ${ }^{108}$ Direct state intervention occurs only when private actors fail to comply with their own standards. ${ }^{109}$ For this reason, much of the 'governance that shapes the daily lives of most citizens today is corporate governance [rather] than state governance'. ${ }^{110}$ This institutional arrangement complements tort law's pursuit of deterrence goals. Almost all medium- and large-size organisations are subject to elements of decentred regulation and have systems of standard-setting in place. ${ }^{111}$ It is to these same systems and people - management, compliance personnel, lawyers and employees - that organisations turn in order to prevent worker torts. Their 'internal monitoring capacities and sanctioning resources are harnessed on behalf of external control'. ${ }^{112}$

\section{(c) Organisation}

We move on now to the last of our themes exploring organisational deterrence. According to the model under consideration, medium- and large-size organisations are 'deterrable'

\footnotetext{
${ }^{107}$ R Fairman and C Yapp, 'Enforced Self-Regulation, Prescription, and Conceptions of Compliance within Small Businesses: The Impact of Enforcement' (2005) 27 Law \& Policy 491, 493.

${ }^{108}$ Baldwin, Cave and Lodge, above n96, pp 65 and 266.

${ }^{109}$ Saurwein, above n103, p 336; J Black, above n102, pp 8-9.

$110 \mathrm{~J}$ Braithwaite, Regulatory Capitalism (Cheltenham: Edward Elgar, 2008), p 4.

${ }^{111} \mathrm{~J}$ March and H Simon, Organizations (Cambridge, Mass.: Blackwell, $2^{\text {nd }}$ ed, 1993), p 23.

${ }^{112}$ Saurwein, above $\mathrm{n} 103,343$. See also C Parker, The Open Corporation: Effective Self-regulation and Democracy (Cambridge: Cambridge University Press, 2002), pp 15 and 29.
} 
because they have advanced capacities to respond to tort law's demands and to implement appropriate standards of conduct. Discussion will focus here upon medium-size companies (MSCs) because they are representative of vicarious liability defendants. Let us hypothesise an MSC manufacturing several products, which has a few hundred employees whose work is coordinated through its managerial structure. The MSC operates in a network of companies, each of which specialises in activities along the chain of manufacture and distribution. At first, we assume the MSC to be a 'high reliability organisation' (HRO), which is self-reflective, always considering how best to respond to risks. ${ }^{113}$ Later, in testing the durability of our model, we will relax this assumption.

Rational subjects of the law strive to adhere to legal rules on account of their lawabiding character and desire to do the right thing. ${ }^{114}$ They are likely to be wary of the criminal law, with its prohibitions designed to protect important public interests. It would be hoped that they would pay just as much heed to tort rules. But the lesser stigma attached to tort liability might mean that profit-oriented companies pay heed to vicarious liability judgments only if doing so is 'good for business'. Indeed, we shall make this assumption of our otherwise high reliability $\mathrm{MSC}^{115}$ in order better to test the strength of the deterrability argument. Even under this assumption, constructive responses to vicarious liability judgments should be expected because they are rational and good for business. The company will want to avoid

\footnotetext{
${ }^{113}$ D Vaughan, 'Organizational rituals of risk and error' in B Hutter and M Power (eds), Organizational Encounters with Risk (Cambridge: Cambridge University Press, 2005), p 57.

${ }^{114}$ MA Eisenberg, 'Corporate Law and Social Norms' (1999) 99 Colum LR 1253, 1257-8.

${ }^{115} \mathrm{Eg}$, Friedman, above n5, p 213; Parker, above n112, pp 63 and 67.
} 
regulatory concerns, contain its financial liabilities, preserve its reputation, and focus upon core business issues. ${ }^{116}$

The discussion proceeds by considering actions that should take place after a judgment has been given holding an MSC vicariously liable for the commission of a tort. Each of the major steps in the journey from judgment to prevention of future wrongdoing is examined. The focus is upon specific deterrence. According to Hodges, a 'prerequisite for a deterrent effect is that actors must ... have the capacity to anticipate that certain actions will cause harm and the potential for liability, and be able to take steps to avoid that harm' ${ }^{117}$ We will see that the deterrable organisation model suggests that deterrence results from the forward-looking nature of organisational decision-making, ${ }^{118}$ the structures through which decisions are implemented, managerial ability to compel workers to comply with decisions, and the ability to formulate norms of behavior for workers under organisational control.

\section{(i) RECEIPT OF JUDGMENT AND SENSE-MAKING}

The immediate significance of a vicarious liability judgment will depend upon various factors, including the award's size and expected operational impact. ${ }^{119}$ Large awards have the potential to raise alarm bells, but so too do modest awards which portend a wide sphere of liability. In the case of large awards, senior management is likely to order a review of the company's liability position as part of its risk planning process, an investigation of fault, and

\footnotetext{
${ }^{116}$ Eg, Eisenberg, above n114, pp 1257-8.

${ }^{117}$ Hodges, above n24, p 53:

118 DeMott, above n87, p 54.

${ }^{119}$ AF Popper, 'In Defense of Deterrence' (2012) 75 Albany LR 101, 105.
} 
the drawing up of reform plans. ${ }^{120}$ Less significant awards will be handled, initially, by inhouse lawyers and/or the regulatory compliance team. ${ }^{121}$ They will construe the judgment ${ }^{122}$ and prepare advice about what it entails for the company's compliance officers and middlemanagers. ${ }^{123}$ In both scenarios, a liability award acts as a 'disturbing event' which serves to alert the company to the existence of a dysfunction, which triggers its 'standard operating procedures $^{\prime 124}$ and initiates a process of deterrence.

(ii) INVESTIGATING FAULT AND RESPONSIBILITY

When a court finds fault in a company, often this will indicate the need for changes to business practices. As such, a norm or standard will be formulated for future action. The company's lawyers/compliance team will inform middle-managers of the need for adherence to the new norm. In the typical case of vicarious liability, where an award of compensation is made without enquiry into fault, ${ }^{125}$ an investigation by the company might be warranted in order to determine what went wrong. This might be conducted, in the case of intentional misconduct, by lawyers, compliance officers, and/or human resources personnel, and, in the case of accidents, by compliance officers and/or health and safety representatives. Unions might become involved. ${ }^{126}$ Properly-trained investigators will consider whether the

\footnotetext{
${ }^{120}$ MA Cohen, M Gottlieb, J Linn and N Richardson, 'Deepwater Drilling: Law, Policy, and Economics of Firm Organization and Safety' (2011) 64 Vand LR 1853, 1856.

121 Parker, above n112, p 115.

${ }^{122}$ WR Scott, Institutions and Organizations (Thousand Oaks, Calif.: Sage, 4th edn, 2014), pp 237-8.

${ }^{123}$ BM Hutter (ed), Anticipating Risks and Organising Risk Regulation (Cambridge: Cambridge University Press, 2010), p 13.

124 M Dan-Cohen, 'Sanctioning Corporations' (2010) 19 J of Law \& Policy 15, 29-30.

${ }^{125}$ Compare, eg, Gravil v Carrol [2008] ICR 1222.

${ }^{126}$ Eg, Parker, above n112, p 254.
} 
conditions that led to wrongdoing are systemic and likely to repeat themselves. Where repetition is likely, the organisational response might entail alterations to structures, systems, and processes.

\section{(iii) ORGANISATIONAL LEARNING AND CHANGE}

Company investigations into systemic problems and/or individual fault connote a learning process. The company seeks to educate itself about what has gone wrong so as to avoid future problems. Most MSCs are organised into functional units such as senior management, research and product development, production, marketing, and sales. ${ }^{127}$ Specialisation of function in each unit usually ensures high technical expertise and substantial operational experience. A significant proportion of decision-making powers are delegated from senior management to middle managers. ${ }^{128}$ Middle managers have oversight of limited numbers of individuals, and their main responsibility is to coordinate work. ${ }^{129}$ But they have an implicit obligation also to ensure that operations evolve as the business environment changes. This means being open to innovation and doing things differently. Success brings greater resource to the unit. Indeed, managers who are able to improve performance will be rewarded personally. As such, they should have a natural incentive to formulate solutions to the problems which vicarious liability judgments signal. The experience of dealing with problems becomes part of corporate memory. Lessons learned are recorded in policies and operational manuals and/or invoked in training programmes. ${ }^{130}$

\footnotetext{
127 HA Simon, Administrative Behavior (New York: Free Press, $4^{\text {th }}$ edn, 1997), pp 265-67.

${ }^{128}$ DS Pugh, 'Does Context Determine Form?', in DS Pugh (ed), Organization Theory: Selected Classic Readings (London: Penguin, 5th edn, 2007), p 34.

${ }^{129}$ SM Bainbridge, 'Why a Board? Group Decision Making in Corporate Governance' (2002) 55 Vand LR 1, 7.

${ }^{130}$ Simon, above n127, p 218; Bainbridge, above n129, p 20.
} 


\section{(iv) FORMULATION OF A RESPONSE}

Typically, the formulation of responses to legal problems involves identifying potential solutions, evaluating them, and choosing one for managerial authorisation. ${ }^{131}$ The ability to implement initiatives applicable to large groups of people is where organisations excel. Organisations restrain, direct, and control the actions of workers through rules, policies, processes, supervision, reporting, training, and culture. ${ }^{132}$ These 'integration mechanisms' are designed to orient action towards company goals, to limit individual discretion, and to embed standards of interaction. These standards promote the coordination of activity in order to achieve unity of effort and efficiencies in worker interactions. ${ }^{133}$ As such, organisations operate as 'regulative frameworks'. ${ }^{134}$

Embedded standards of interaction are prominent especially in manufacturing and other sectors that require operational precision. ${ }^{135}$ They are less prominent in the services sector and in industries undergoing rapid change, where less-structured operations prevail, decision-making authority is pushed down to those most informed of local conditions, ${ }^{136}$ and coordination is achieved through informal processes of 'mutual adjustment'. ${ }^{137}$ However, even in these organisations some operational issues remain under senior management

\footnotetext{
${ }^{131}$ Mintzberg, above n31, p 58.

132 Hatch, above n24, pp 113 and 150-1.

${ }^{133}$ Scott, above n124, p 29; Hatch, above n24, p 101.

${ }^{134}$ Scott, above n124, p 81.

135 Hatch, above n24, p 103.

136 Ibid p 102.

137 Ibid pp 99-100; Mintzberg, above n31, pp 3, 86-7, 270-1 and 276.
} 
control $^{138}$ - especially as regards compliance with criminal law, governmental regulation, and health and safety standards. HROs frequently take a prescriptive approach, in order to meet regulatory requirements, and establish clear worker responsibilities.

Fisse and Braithwaite believe that 'it is possible for corporations to be held to different and higher standards of responsibility than individuals because of their ... capacity as organisations' ${ }^{139}$ They have the ability to use integration mechanisms not only to promote workplace efficiency, but to reduce areas of individual discretion and prevent the commission of torts. Specific actions they might take in response to vicarious liability judgments include:

- Changes in rules and procedures: Senior management must design systems to counter inevitable human errors as well as person-specific behavioural tendencies spanning from laziness to predatory sexual conduct. ${ }^{140}$ In cases where individual workers transgress and commit torts, senior management should ensure the existence of an effective system of internal discipline. ${ }^{141}$ Disciplining workers is a necessary concomitant of the company's establishment and promotion of norms of conduct. ${ }^{142}$ While it is not possible always to prevent wrongdoing, the mere fact that the company will pay for worker wrongs provides ongoing incentives to try.

\footnotetext{
${ }^{138}$ Mintzberg, above n31, pp 107-8.

${ }^{139}$ Fisse and Braithwaite, above n105, p 27.

${ }^{140}$ See, eg, Cohen, Gottlieb, Linn and Richardson, above n120, p 1856.

${ }^{141}$ Fisse and Braithwaite, above n105, pp 57, 79 and 97.

142 Ibid p 97.
} 
- Changes in personnel etc: The success of a company depends on hiring staff with appropriate skills and aptitudes and screening out those with unwanted traits. Many developments in vicarious liability have taken place in the context of the sexual abuse of children. Here we must digress from our manufacturing MSC in order to consider what the deterrable organisation model says about problems arising in schools and childcare organisations. Workers who commit abuse conceal their misdeeds, making it difficult to take action against them. Yet courts insist that organisations have a key role to play in preventing abuse. Precautions include background checks, psychological testing, implementation of formal procedures for undertaking risky activities, monitoring of workers, checks on vulnerable children, procedures for making complaints and investigating them, warnings and other kinds of reproach, transfer or removal from places of work, and dismissal.

- Changes in lines of accountability: The company should be able effectively to monitor middle-managers with delegated powers and operations managers responsible for risky processes and the conduct of individuals. ${ }^{143}$ In the case of simple physical processes, managers supervise personnel directly. In cases involving more sophisticated ways of working, there might be a need to educate and train workers, to introduce improved procedures, and/or reporting. Evidence suggests that, frequently, knowledge of gaps in safety standards and other problems is present before wrongs occur, but that it fails to make its way to managers. ${ }^{144}$ This emphasises the importance of proper internal disclosure and accountability systems by which information makes its way from worksites to managers.

\footnotetext{
143 Parker, above n112, p 116.

${ }^{144}$ Cohen, Gottlieb, Linn and Richardson, above n120, p 1869.
} 
- Changes in incentive systems: Although this paper is written from an organisational/systems perspective, it is notable that economic analysts of law pay considerable attention to the use of incentives within organisations. They argue that strict liability is the best mechanism for inducing efficient levels of risky activity because it ensures that all costs of activity are absorbed by the relevant 'enterprise' ${ }^{145}$ Enterprises will want to avoid risky activities that are unprofitable. Beyond this, the 'employer's influence over advancement and compensation decisions provides an[ ] important incentive device... [A]s long as the employee values the employment relationship, these incentives can act as an effective constraint' upon employee behaviour. ${ }^{146}$

- Organisational culture: In addition to the creation of formal standards and the operation of group dynamics, organisations seek positively to influence worker conduct through 'organisational culture'. A strong culture ensures that managers and workers are 'on the same wavelength'. It subsists in shared values and understandings transmitted through recruitment and training as well as socialisation processes, including job rotation, social events, and casual

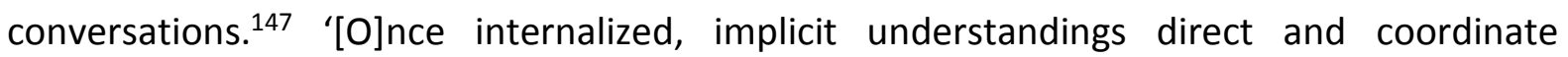
employees' behavior and cause them to internally monitor their own behavior and that of others' ${ }^{148}$ In this way, organisational culture reinforces perceptions that participants are pursuing common goals, which encourages them to adhere to rules and procedures, and strengthens group dynamics.

\footnotetext{
${ }^{145} \mathrm{G}$ Calabresi, The Costs of Accidents (New Haven: Yale University Press, 1970), p 69.

${ }^{146}$ AO Sykes, 'The Boundaries of Vicarious Liability: An Economic Analysis of the Scope of Employment Rule and Related Legal Doctrines' (1988) 101 Harvard LR 563, 570.

${ }^{147}$ Hatch, above n24, p 185; Mintzberg, above n31, p 98.

${ }^{148}$ Hatch, above n24, p 185.
} 
- Changes in industry partnerships: Often companies work in networks, ${ }^{149}$ which are contractbased agreements for the supply of goods and services. These arrangements might be implemented for reasons related to the availability of know-how and/or efficiency of operations. Sometimes, however, the motivation for entering into network agreements is to escape responsibility for employment obligations and this 'benefit' has resulted in widespread outsourcing and offshoring. Despite the contractual nature of networking agreements, an MSC might be in 'control' of industry partners dependent on it for business. ${ }^{150}$ It might be able to influence standards adopted by network partners through contracting and supervision processes. ${ }^{151}$ Widening the net of vicarious liability so as to include some responsibility for the torts of independent contractors could lead to changes in contracting relationships which improve standards and reduce worker wrongdoing.

\section{(v) INTERNAL TRANSMISSION: MANAGERIAL AUTHORITY}

A chart of managerial responsibility outlines where individuals are placed within the MSC's decision-making and command structure. ${ }^{152}$ Decisions run down the chain of command, creating a managerial ability not only to coordinate action but to impose decisions upon the unwilling. Assuming that senior management desires change, it can achieve this by using its authority to alter rules, policies, processes, and so on. ${ }^{153}$ In the usual case, there is no need

\footnotetext{
${ }^{149}$ Eg, G Teubner, Networks as Connected Contracts (tr M Everson)(Oxford: Hart, 2011).

${ }^{150}$ Barclays Bank plc v Various Claimants [2018] IRLR 947, [45].

${ }^{151}$ Hodges, above n24, p 49; Parker, above n115, pp 99 and 223.

152 Hatch, above n24, pp 92-3 and 242; T Isaacs, Moral Responsibility in Collective Contexts (Oxford: Oxford University Press, 2010), p 98.

153 Simon, above n127, pp 112 and $179 f f$.
} 
to exercise authority in a heavy-handed way because subordinates understand that they cannot make their own, personal choices, and must comply with management initiatives. ${ }^{154}$ Indeed, a positive organisational culture will smooth the way to compliance. In our hypothetical MSC, the Chief Executive Officer and board of directors are at the managerial apex. They set the company's policy direction with the advice of senior managers, experts, and technicians. Given that our MSC manufactures several products, it is likely to have multiple functional units that align product-types and markets. ${ }^{155}$ The middle-managers leading these units will adopt the integration mechanisms best suited to achieve change and/or reduce individual worker discretion. ${ }^{156}$

\section{(vi) EXTERNAL TRANMISSIONS: REPUTATION AND MIMICRY}

Even beyond 'general deterrence', change within one organisation has the potential to spur changes in others ${ }^{157}$ because they are 'nested' within society and experience pressures to conform to best practice. Best practice is disseminated through various channels, including professional/trade association guidelines, ${ }^{158}$ insurer initiatives, publicity, movement of staff, and so on. ${ }^{159}$ Scott found these mimetic processes in operation after alterations to equal opportunity and medical malpractice laws. ${ }^{160}$ Change rippled through organisations as managers and others sought to make sense of new laws and engaged in problem-solving

\footnotetext{
${ }^{154} \mathrm{Ibid}$ pp 180 and 184-5.

155 Mintzberg, above n31, pp 190-1.

${ }^{156}$ E v English Province of Our Lady of Charity [2013] QB 722, esp. [20].

${ }^{157}$ Eisenberg, above n114, pp 1269-70.

158 Parker, above n112, p 224.

${ }^{159}$ Scott, above n122, p 199.

160 Ibid ch 7.
} 
activities that influenced whole organisational fields. ${ }^{161}$ This demonstrates the potential in a corporatised world for judicial signals to initiate wide change.

(vii) RELAXING THE HIGH-RELIABILITY ASSUMPTION

We have now considered the steps that the ideal, profit-focussed MSC should take in response to a vicarious liability judgment. As stated, the ideal is an HRO, which is selfreflective, always considering how best to respond to risks. But not all companies are HROs. As such, we should relax this assumption now and consider where gaps might arise in processes of organisational deterrence. We commence with some observations about the reality of deterrence. Judicial belief in the possibility of deterrence is a product of judges' 'internal' views that laws help guide future conduct. In cases where persons fail to observe tort rules, they are subject to penalties that include injunctions and damages awards. The threat of liability ought to bring about changes in behaviour. But there is an on-going debate about the empirical validity of the idea that tort deters.

Opportunities for deterrence are influenced by both the type of tort (doctrine) in issue and the type of defendant. As noted, some torts offer more guidance than others. Definitional torts are more helpful than is negligence. Furthermore, it would appear that industrial and other recurring activities are more amenable to deterrence because defects usually are capable of 'technical' fixes. By contrast, the activities of sexual predators are problematic, given the vagaries of individual preferences and motivations to act. ${ }^{162}$ Yet, tort law does not operate in a vacuum. It is one of a range of mechanisms by which the state seeks to shape

\footnotetext{
161 Ibid p 209.

${ }^{162}$ E v English Province of Our Lady of Charity [2013] QB 722, [52].
} 
conduct. Tort law has a role in reinforcing the criminal and regulatory law and can make a difference to outcomes - given the ways in which organisations, such as schools and councils arranging foster care, can act to prevent abuse, and given anecdotal evidence of the ways in which they have reacted to liability 'scares' in the past.

Again, tort law's efficacy as a deterrent will depend upon who the defendants are. Individuals are prone to indiscretions and lapses that cannot be eliminated completely. Organisations and professional persons are more likely to act in rational ways ${ }^{163}$ and should be more easily deterred by tort rules. ${ }^{164}$ They have access to legal advice, professional association guidance (in some cases, mandatory standards are imposed), ${ }^{165}$ and training opportunities. Indeed, it would appear that most employer organisations know of their vicarious liability for worker wrongs. ${ }^{166}$ Greater difficulty might lie in ascertaining the details of the torts for which they could be held liable. But even here, they would have a reasonable understanding that worker activities that endanger safety and wellbeing can be subject to claims. And organisations have the capacity to bring about changes in worker behaviour.

But what does the evidence tell us about the reality of deterrence? The evidence is not entirely helpful. Many shortcomings boil down to a lack of meaningful data, to the operation of overlapping rules in criminal, regulatory and and tort law, and to problems in

\footnotetext{
${ }^{163}$ WJ Cardi, RD Penfield and AH Yoon, Does Tort Law Deter Individuals? A Behavioral Science Study' (2012) 9 J Emp LS 567, 597.

${ }^{164}$ Friedman, above n5, p 76.

165 Ibid p 16.

166 Ibid pp 17-20.
} 
proving relationships of cause (rule or no rule) and effect (wrong or no wrong). ${ }^{167}$ In this way, testing of hypotheses about deterrence must be undertaken by using surrogate experimentation. 'Evidence' from surrogate testing is tentative, open to refutation, and frequently unreliable. Having said as much, the evidence from meta-studies is that regulatory/tort law does deter, if only modestly, ${ }^{168}$ and that the effect is greatest upon governmental agencies ${ }^{169}$ and larger companies. ${ }^{170}$ Moreover, deterrence is more likely to be realised with respect to organisations that have been subject to legal actions themselves (specific deterrence) than with respect to those that simply learn from the experience of others (general deterrence). ${ }^{171}$ Larger companies especially are compliant with regulatory/tort norms because they: are monitored internally through corporate governance arrangements and in-house compliance units ${ }^{172}$ and externally by stakeholders such as creditrating agencies and corporate advisory firms; ${ }^{173}$ have a community 'presence' and must be mindful of their reputations; ${ }^{174}$ and have the financial wherewithal to implement good norms of conduct. ${ }^{175}$ Small companies are less likely to be deterred because of their lack of

\footnotetext{
${ }^{167}$ Cardi, Penfield and Yoon, above n163, pp 570-1.

${ }^{168}$ Friedman, above n5, 137; Cardi, Penfield and Yoon, above n163, p 574.

169 JF Spriggs, 'The Supreme Court and Federal Administrative Agencies: A Resource-Based Analysis of Judicial Impact' (1996) 40 Am J Political Science 1122.

${ }^{170}$ Hodges, above n24, p 39.

${ }^{171} \mathrm{lbid} \mathrm{p} 143$.

172 Ibid p 40.

${ }^{173}$ RA Kagan, N Gunningham and D Thornton, 'Fear, Duty, and Regulatory Compliance' in C Parker and V Lehman Nielson (eds), Explaining Compliance: Business Responses to Regulation (Cheltenham: Edward Elgar, 2011), ch 2.

${ }^{174}$ Friedman, above n5, pp 164 and 173; Parker, above n112, p 77.

${ }^{175}$ Parker, above n112, p 96.
} 
knowledge of what the law requires, ${ }^{176}$ lower financial margins, ${ }^{177}$ and tendency to do the minimum necessary to comply with legal obligations. ${ }^{178}$

These findings support the viability of the deterrable organisation model, which concentrates upon 'bureaucratic' middle- and large-size entities. But this is not to say that deterrence processes are as effective as the model would assume. What are the problems? We consider here the potential 'bottlenecks' and 'choke points' in organisational responses to vicarious liability awards. ${ }^{179}$ Responses to deterrence imperatives might be compromised by one or more of the following problems:

- Senior managers do not always have either the time or ability to focus upon all operational issues. They must set priorities, as must other organisational personnel, so that responding to vicarious liability judgments might not be treated as especially important; ${ }^{180}$

- Senior managers who accept the need for reform might determine that the costs of change will be high and that no commitment should be made to it either because resources are not available, or because alternative 'business cases' for the use of funds are more attractive. This type of problem will be acute among organisations in the vicinity of insolvency; ${ }^{181}$

\footnotetext{
${ }^{176}$ Fairman and Yapp, above n107, p 510.

${ }^{177}$ Friedman, above n5, p 213.

178 See Fairman and Yapp, above n107.

${ }^{179}$ Friedman, above n5, p 146; Parker, above n112, p 147.

180 Simon, above n127, p 90.

${ }^{181}$ Friedman, above n5, p 243.
} 
- Even if adequate resources are available, organisational staff might not have information required for good decision-making. They might be unable to make sense of vicarious liability judgments or analyse adequately problems affecting their organisations. Indeed, Simon believed such problems to be endemic, leading to his insight that decision-makers suffer from 'bounded rationality'. However, he believed also that organisations can overcome individual shortcomings; ${ }^{182}$

- Even where correct prognoses are made in response to vicarious liability judgments, the forces of inertia might be strong. These might be grounded, for example, in established practices or vested interests; ${ }^{183}$ and

- Organisations might try to dodge responsibility for torts by outsourcing work. ${ }^{184}$ The recent widening of vicarious liability so as to create liability for the torts of non-employees - who might be independent contractors ${ }^{185}$ - is likely to reduce this temptation.

These bottlenecks and choke points need to be addressed and something more will be said about this issue momentarily. But before doing so, we should deal briefly with another objection to deterrence reasoning, which is that insurance 'cushions' tort's deterrent

\footnotetext{
182 Simon, above n127, pp 89, 93-102 and 106-117.

${ }^{183}$ MT Hannan and J Freeman, 'The Population Ecology of Organizations' in DS Pugh (ed), Organization Theory: Selected Classic Readings (London: Penguin, 5th edn, 2007), pp 186-8.

184 JH Arlen and WB MacLeod, 'Beyond Master-Servant: A Critique of Vicarious Liability' in MS Madden (ed), Exploring Tort Law (Cambridge: Cambridge University Press, 2005), p 118.

185 Barclays Bank plc v Various Claimants [2018] IRLR 947.
} 
effect. ${ }^{186}$ Several responses can be made to this claim. First, following a government austerity drive, many public authorities and state-owned enterprises have reduced their reliance upon commercial insurance and/or have become self-insurers. ${ }^{187}$ Second, many companies are insured by 'captive insurers' in the same corporate group, these groups being 'selfinsurers' ${ }^{188}$ Third, organisations with commercial insurance have many reasons to be concerned about their exposure to tort liabilities. Insurers might insist upon risk-management regimes or monitor their conduct. ${ }^{189}$ Their agreements with assureds impose obligations of care. ${ }^{190}$ Excess clauses operate to align the interests of insurers and assureds, ${ }^{191}$ insured amounts being subject to claims limits so that there is a risk that assureds will need to make contributions, and employers found vicariously liable for the commission of torts face reputational damage in the eyes of employees and customers. ${ }^{192}$ Fourth, insurers undertake educative functions to increase standards of safety, health, and so on, and to reduce the number of claims made. For these reasons, the supposed 'cushioning' effect of insurance is over-played and cannot be equated with a smothering of deterrence.

\footnotetext{
186 Giliker, above n33, p 242.

${ }^{187}$ W Kirkman, 'Public bodies forced to self-insure due to government cost cutting', Insurance Post (2 February 2017); available at https://www.postonline.co.uk/2481181/public-bodies-forced-to-self-insure-due-togovernment-cost-cutting.

188 I thank Rob Merkin for these points.

${ }^{189}$ R Merkin and J Steele, Insurance and the Law of Obligations (Oxford: Oxford University Press, 2013), pp 141 and 322 .

190 Ibid p 43.

191 JD Hanson and KD Logue, 'The First-Party Insurance Externality: An Economic Justification for Enterprise Liability (1990) 76 Cornell LR 129, 142.

192 JC Coffee Jr, “'No Soul to Damn No Body to Kick': An Unscandalized Inquiry into the Problem of Corporate Punishment' (1981) 79 Mich LR 386, 433.
} 


\section{PRESCRIPTIONS}

There is always 'slippage' in the space between law and compliance. Even so, findings from the empirical literature on deterrence suggest that the deterrable organisation model is likely to need bolstering in order to ensure that organisations take effective action to prevent the commission of worker wrongs. Here we move from the interpretive stage of our consideration of vicarious liability to the post-interpretive stage. This means making prescriptions for improvements to legal practices.

A first prescription affirms the wisdom of widening the net of vicarious liability so as to encompass some non-employees. This ought to be encouraged because it is likely to lead to a renewed sense of responsibility in organisations for wrongdoing which occurs in connection to their activities. Indeed, Arlen and McLeod argue in favour of extending vicarious liability to independent contractors in order to avoid the inherent subsidy which arises when organisations use thinly-capitalised independent contractors to undertake risky work. Such independent contractors operate on the premise of low expected tort liabilities ('low' because they will be unable to pay more than nominal sums), which enables them to charge less for their work. ${ }^{193}$ This leads to moral hazard and excessive risk-creation. Arlen and McLeod's analysis supports 'expanding the reach of entity-level liability to certain organisations which hire independent contractors' ${ }^{194}$ The key issue in the imposition of vicarious liability is whether 'an organisation could have structured its relationship with the agent to allow it to influence the agent's behaviour'. ${ }^{195}$ Naturally enough, courts must not go

\footnotetext{
${ }^{193}$ Arlen and MacLeod, above n184, p 114.

194 Ibid p 115.

195 Ibid p 136.
} 
too far in diverting responsibility from independent contractors to deterrable organisations for fear that this would dissuade the latter from using outside experts when necessary ${ }^{196}$ or that it would create responsibility where control could not be exercised over independent contractor activities. ${ }^{197}$

The second prescription entails use of the right remedies so that deterrence outcomes are maximised. Here we need to keep in mind the fact that vicarious liability is not liability without fault and that it might function as a proxy for fault. This justifies the use of remedies designed to bring about reform of conduct. Existing rules on damages can facilitate this, although there is a question about their efficacy. Where worker conduct is egregious and exemplary damages are awarded in order to punish and deter, the vicariously liable employer must pay the full award. ${ }^{198}$ The size of the award will be calculated according to the resources available to the employer rather than to the tortfeasor. ${ }^{199}$ This could result in very high awards in sexual abuse cases and bring tort law into line with the criminal law in terms of its deterrent potential. Moreover, where the employer is made liable in successive cases of vicarious liability, this creates an opportunity for future claimants to plead systemic negligence against the organisation itself - meaning that claimants are able to plead the commission of torts by both workers and organisation.

\footnotetext{
${ }^{196}$ M Tutin, 'Vicarious liability: an ever-expanding concept?' (2016) 45 Ind L 556, 563.

${ }^{197}$ Eg, 671122 Ontario Ltd v Sagaz Industries Canada Inc [2001] 2 SCR 983, [34]-[35].

${ }^{198}$ Rowlands v Chief Constable of Merseyside [2007] 1 WLR 1065, [47]('Rowlands'). See also Racz v Home Office [1994] 2 AC 45.

${ }^{199}$ Rowlands [2007] 1 WLR 1065, [47].
} 
Beyond the ability to order payment of damages, the English High Court has several powers that could help to bring about reform of organisations and of worker conduct, including powers to issue injunctions ${ }^{200}$ and to make declarations. An action for vicarious liability might support the award of a prohibitory injunction against an organisation aimed at preventing the commission of future wrongs. In cases where the evidence adduced reveals lapses in organisational structures and practices, courts might be prepared to go further and grant mandatory injunctions directing organisations to carry out reforms. But courts will do so only when their terms can be made certain enough. ${ }^{201}$ It is likely that courts would be readier to grant declaratory relief pursuant to their inherent jurisdiction, ${ }^{202}$ framed in terms of the need for investigation of structures and practices and for reform. ${ }^{203}$ The main limit to the grant of declaratory relief is that it must serve a real purpose in ordering legal relations between parties 204 - which, in the present context, does not present a high hurdle.

At the moment, injunctions and declarations are used infrequently in vicarious liability cases. It might be necessary to consider further ways in which remedies could be structured so as to induce reform and to insist upon follow up, for example through progress reporting. This idea would cohere with developments in the criminal law, where there has been movement towards use of non-monetary orders against organisations so as to bring about their rehabilitation. US prosecutors make use of deferred prosecution agreements in order to

\footnotetext{
200 Senior Courts Act 1981, s 37(1).

${ }^{201}$ A Burrows (ed), Principles of The English Law of Obligations (Oxford: Oxford University Press, 2015), pp 372 and 386 .

202 Senior Courts Act 1981, s 19. See CPR 1998, r 40.20.

203 Burrows, above n201, p 389.

${ }^{204}$ San Juan v Allen [2016] EWHC 1502 (Ch).
} 
induce 'structural change'. 'Managers can be fired, new leadership can adopt compliance programs and governance reforms, and independent monitors can review changes to policies and practices' ${ }^{205}$ Deferred prosecution agreement orders can be made in the UK too, for the purposes of implementing a compliance programme or making changes to an existing compliance programme relating to an organisation's policies or to the training of their employees. ${ }^{206}$ Similar methods of bringing about change have been used occasionally in civil law, although normally at the behest of government agencies enforcing regulatory standards. For example, in In re Oil Spill by the Oil Rig "Deepwater Horizon", 207 the US District Court made consent orders aimed at improvement of safety practices, contractor oversight, corporate governance, senior manager training, internal auditing of compliance, and external monitoring of activities. However, such orders are possible only when there is evidence of failures in organisational systems and, in the absence of actions based on systemic negligence, this might require the development of a power in courts to order preliminary investigations into such matters.

Experience from regulatory law suggests that court orders specifying the need for investigations into their structures and/or for changed practices must be subject to followup. ${ }^{208}$ Mechanisms could be put in place to ensure monitoring of investigations and/or changes being implemented, which would not require the constant involvement of courts. Instead, these might involve court-appointed experts ${ }^{209}$ or task forces of organisational

\footnotetext{
${ }^{205}$ BL Garrett, 'The Corporate Criminal as Scapegoat' (2015) 101 Virginia LR 1789, 1838.

${ }^{206}$ Crime and Courts Act 2013, s 45 and sch 17.

207 In re Oil Spill by the Oil Rig “Deepwater Horizon” F Supp 3d 657 (ED La 2014).

208 Parker, above n112, pp 234, 282-283.

${ }^{209}$ Garrett, above n205, p 1839.
} 
personnel. ${ }^{210}$ In other cases, it might be appropriate for claimants to seek undertakings by companies and/or their directors that they will reform relevant operations and to either publicise measures taken or file reports in court. In the latter case, reports filed in court could be retained as records that could prove important in the future should there be further transgressions, facilitating arguments of systemic negligence.

\section{CONCLUSIONS}

Much of the classical case law on vicarious liability can be justified on the basis of liberal agency. This justification applies to cases in which owner-managers have personal relations with wrongdoing workers. Typically, such relations are found among small companies, small partnerships, and individual employers. However, agency is a less cogent justification in bureaucratic organisations, in which there are multiple levels of decision-making, indirect communications to workers, and significant areas of individual discretion.

Courts have begun to offer new justifications for the imposition of vicarious liability which are relevant especially to medium- and large-size organisations. This article assembled elements of the reasoning used in cases involving such organisations and used them to construct a model of vicarious liability - the model of the 'deterrable organisation'. The 'deterrability' of bureaucratic organisations was seen to reside in their structures and processes, which can be utilised in imposing norms of good conduct upon workers. The 'delegation' by courts of responsibility for imposing standards upon workers to organisations

${ }^{210}$ Fisse and Braithwaite, above n105, pp 194 and 196. 
themselves coheres with modern notions of decentred regulation - and makes use of the same structures, processes, and personnel.

The organisational deterrence justification of vicarious liability does not preclude reliance upon notions of liberal agency where this is evident in bureaucratic organisations these are mutually supportive justifications for the imposition of vicarious liability upon organisations. What matters is that, for each case of vicarious liability, one or both of the justifications applies so as to signify the appropriateness of the defendant's liability. The deterrable organisation model fills a gap in justifying vicarious liability in non-agency cases.

Finally, the article reflected upon evidence about the reality of deterrence involving bureaucratic organisations. It was seen that scholars have greater faith in deterrence processes involving such organisations than they have in those involving individuals. Even so, the deterrence potential of vicarious liability could be strengthened by courts doing such things as making greater use of exemplary damages and of non-monetary orders aimed at bringing about organisational reform. 